IJOLTL, Vol. 3, No. 2, May 2018

p ISSN: 2502 2326; e ISSN: 2502 8278

Http://ijolt1.pusatbahasa.or.id; Email: ijolt1@gmail.com

Center of Language and Culture Studies, Surakarta, Indonesia

Sudrajat, Didi. 2018. Developing Critical Reading Skills for the Information

and Enjoyment. IJOLTL (2018), 3(1): 147 158. DOI: 10.30957/ijoltl.v3i2.453.

\title{
DEVELOPING CRITICAL READING SKILLS \\ FOR INFORMATION AND ENJOYMENT
}

\author{
Didi Sudrajat \\ University of Kutai Kartanegara \\ Jl. Gunung Belah 12 Tenggarong, East Kalimantan
}

\begin{abstract}
Critical reading has been the issue in teaching reading throughout school programs. The main objective of the critical reading is to achieve comprehension using various reading techniques. Problems of reading comprehension, however, are difficult to handle and institutions require sets of teaching principles in a comprehensive plan. The main problem of critical reading is asking students to involve in the reading manners that conform to the purposes of reading. This paper presents a slight review of literature in teaching reading in general, providing theories on reading comprehension, reading process, and developing critical reading techniques.
\end{abstract}

Key-words: critical reading, comprehension, schemata.

\section{DOI: 10.30957/ijoltl.v3i2.453.}

\section{INTRODUCTION}

This paper reviews critical reading for academic needs and enjoyment. Theories pertaining to academic reading and enjoyment are discussed in this paper. This paper starts from a thesis that critical reading applies for the academic needs and enjoyment. Students are made aware of the implementation in class to encourage their motivation and achieve the skills of the reading.

When we read a passage, there is usually a reason for doing so. In real life, the reasons vary. However, Grellet (1984) classifies them into two main reasons for reading, namely reading for information and reading for enjoyment. Primarily, reading is a means of communicating information between the writer and the reader. The reader tries to understand ideas that the writer has put in print. Vacca, Vacca and Gove in Budiharso, 2006). Reading may involve decoding and comprehension process. Decoding process refers to the process of saying printed words into representation similar to oral language either silently or aloud. In addition, comprehension is the process of understanding the representation (Budiharso, 2006).

Referring to above statement, reading can be done aloud or silently. It may be considered to be reading aloud when the reader enunciates the sounds which are 
IJOLTL, Vol. 3, No. 2, May 2018

p ISSN: 2502 2326; e ISSN: 2502 8278

Http://ijolt1.pusatbahasa.or.id; Email: ijolt1@gmail.com

Center of Language and Culture Studies, Surakarta, Indonesia

Sudrajat, Didi. 2018. Developing Critical Reading Skills for the Information

and Enjoyment. IJOLTL (2018), 3(1): 147 158. DOI: 10.30957/ijoltl.v3i2.453.

symbolized by the written marks on the script in his hand. While in silent reading, the reader will derive meaning from the word communications in the text without necessarily vocalizing what he is reading.

For the purpose of comprehending the text, silent reading has to be occurred. This is based on Dwyer's opinion that:

Reading aloud forces the student to focus on each word (not look at words as a whole for comprehension) and make him struggle to pronounce correctly and deliver expressively what he is reading loudly. These may make the students lose all sense of the meaning of what he is reading (Dwyer, 1983).

Furthermore, Tarigan (1984) states that reading aloud emphasizes more on pronunciation than on meaning, while the main objective of reading comprehension is getting the information or meaning from written materials. Reading, therefore, is a complex process by which a reader reconstructs, to some degrees, a message encoded by a writer in graphic language. To comprehend the text, a reader needs two kinds of information: visual and non visual. Visual information is the written information which must be caught by eyes. Non visual information is the information involving the relevance of language competence, knowledge about the topic being read, and knowledge of the world about reading. Both visual and non-visual information have reciprocal relationship (Smith in Budiharso, 2006).

Lewis (1978) confirms that comprehension is not a single skill, but a composite of related, multiple processes. Therefore, no matter how one lists the various comprehension skills, it is almost impossible to determine the sequence of skills accurately, because each skill is interwoven with others in different relationships depending on the reading task at hand.

Calfee and Drum (1985) present three components which are essential to any act of reading comprehension, namely text, a reader of the text and an interpretation of the text by the reader. In accordance with the information used by the readers during the reading process, Goodman quoted by Bastidas (1986) in The Cloze Procedures as a teaching Technique to Improve Reading Comprehension states that the reader must have a knowledge of the language (semantic, syntactic and graphonemic systems), a knowledge of the story or topic being read, and an understanding of what has happened previously. Briefly, then comprehension depends on the successful processing of these previously stated factors.

Meanwhile, Coady quoted by Carrell and Eisterhold in Schema Theory and ESL reading Pedagogy has elaborated the process to produce comprehension on the basic psycholinguistic model of reading which involves the interaction of reader's background knowledge, conceptual abilities and process strategies. Further, Coady explains that conceptual ability means general intellectual capacity, and processing strategies means 
IJOLTL, Vol. 3, No. 2, May 2018

p ISSN: 2502 2326; e ISSN: 2502 8278

Http://ijolt1.pusatbahasa.or.id; Email: ijolt1@gmail.com

Center of Language and Culture Studies, Surakarta, Indonesia

Sudrajat, Didi. 2018. Developing Critical Reading Skills for the Information

and Enjoyment. IJOLTL (2018), 3(1): 147 158. DOI: 10.30957/ijolt1.v3i2.453.

various subcomponents of reading ability (e.g. grapheme-morpho-phoneme correspondences, syllable-morpheme information, syntactic information, lexical meaning, and contextual meaning).

Briefly, it should be obvious that reading is an interactive process. It is the process of combining textual information with the information a reader brings to a text. In this view the reading process is not simply a matter of extracting information from the text. Rather, it is one in which the reading activities a range of knowledge in the reader's mind that he or she uses. In this regard, reading is viewed as a kind of dialogue between the reader and the text. Understanding of reading is the best considered as the interaction that occurs between the reader and the text, an interpretive process (Grabe in Budiharso, 2006).

\section{THE PROCESS OF READING}

Reading can be considered as a product and as a process. Reading as a process is an activity carried out by the reader in his attempt to get the meaning of a written material. Reading as a product is an ability or skill achieved by the reader which can be measured (Hafni, 1981). In order to achieve or to get the meaning of a written material, the reader must, of course, process a good reading act in the reading process.

The process of reading can be divided into two parts, i.e., visual process and comprehension process. Visual process is an activity carried out by eyes, while comprehension process is carried out by mental activity. Strevens (1983) describes the process of reading as deciphering and decoding. Deciphering is a form of pattern recognition which includes, i) distinguishing writing from other kinds of patterns, ii) learning the letter shapes, iii) becoming accustomed to the direction of writing, iv) findings beginnings and ends, v) learning to adjust the rate learning how to refer back or forward to resolve ambiguity or doubt. He also explains that the second process of reading is decoding is part of the total process of comprehension. So far he describes that reading skills linking the flow of deciphered information to the reader's knowledge of the language -its grammar, vocabulary, semantics, pronunciation- and that of the nature. To his opinion the reader has to bring together vision, hearing, memory, and imagination in order to discover the meaning, to interpret it, and to put it into action, and finally the language he has read is assimilated into his total experience.

Citobroto (1982) also agrees that the process of reading consists of two steps. He believes that reading is not only combining letters into syllable, syllables into word, words into sentences and so on, but the first step of reading is that the reader should look at group of words, which he calls it as recognition process. Then the reader stops for a moment to predict and interpret what he has read. He calls this second step or process as fixation process.

Abbot et al. (1981) also support the above mentioned idea. They describe the nature of reading as visual task and cognitive task. Further they explain the visual task as the deciphering marks on the page, and receiving the signals from the brain by the eyes. 
IJOLTL, Vol. 3, No. 2, May 2018

p ISSN: 2502 2326; e ISSN: 2502 8278

Http://ijolt1.pusatbahasa.or.id; Email: ijolt1@gmail.com

Center of Language and Culture Studies, Surakarta, Indonesia

Sudrajat, Didi. 2018. Developing Critical Reading Skills for the Information

and Enjoyment. IJOLTL (2018), 3(1): 147 158. DOI: 10.30957/ijoltl.v3i2.453.

Secondly, cognitive task, to their opinion, is the interpretation of the visual information so that one is not simply 'breaking at the print.' They describe the second process as the reconstruction taking place in the reader's mind. This process concerns with the thinking skills and covers the reader's attempt to build up the meaning the writer had in mind when he wrote the text.

Another point of view is stated by Olson and Ames (1972). To their opinion the first step of reading is identifying the word symbols on the printed page, and the second is associating them or reacting to them with a group of mental association.

\section{DEVELOPING CRITICAL READING SKILLS}

To develop the students' critical reading skills can be improved by developing the students' skills for and awareness of aspects necessary for critical reading. The aspects are covered denotation and connotation, figurative language, and distinguishing facts from opinions.

\section{Denotation and Connotation}

All words refer to something. If we look up a word in the dictionary it will give us the meaning of the word, namely what that word denotes. Denotation, then, is the meaning of a word as we would find in the dictionary. However, the connotative meaning of a word is normally not found in the dictionary. It is the associated meaning that a word has. For example if we look up the word red in the dictionary, it will tell us that red is the name of a certain color. But we also know that the word red is also used to mean communist. We will not find this meaning in the dictionary because it is the connotative meaning of the word red.

Connotation can be general or personal. The connotative meaning of red as communist is general, because many people would understand if we use the word red to mean communist. On the other hands, the word school or home may have different connotative meaning for different people, depending on the experiences each one has in those places.

The connotative meanings of words are often used in advertising and political speeches to make us believe their assertions and buy their goods or ideas. Some people in advertising do not like to use the word cheap because it has a connotation of shoddiness, poor workmanship and poor quality. They prefer to use the word affordable instead. Similarly, fat is an unattractive word; no one likes to be called for (or admit that he or she is), therefore clothing manufactures would use terms like large or outsize.

However, connotations are not only used for the purpose of deceiving or persuading people. Creative writers often use word-connotation to give a clearer description of things we do not normally see, feel, or hear. In reading or listening to advertisements and political speeches we must be on guard against deception, but in reading creative writers (literature) 
IJOLTL, Vol. 3, No. 2, May 2018

p ISSN: 2502 2326; e ISSN: 2502 8278

Http://ijolt1.pusatbahasa.or.id; Email: ijolt1@gmail.com

Center of Language and Culture Studies, Surakarta, Indonesia

Sudrajat, Didi. 2018. Developing Critical Reading Skills for the Information

and Enjoyment. IJOLTL (2018), 3(1): 147 158. DOI: 10.30957/ijoltl.v3i2.453.

we must be receptive to the connotative meanings of the words so that we can see what the writer sees, hear what he or se hears, and feel what he or she feels.

Some words have strong emotional values and they are often used for their connotative meanings. For example: ambition, beauty, country, courage, destiny, freedom, friendship, glory, grief, harmony, home, hope, justice, youth, etc..

Wordsworth wrote the following line to describe the quietness of a beach. Notice how he skillfully uses words connote quietness, and enable us to see and feel everything as if we were there watching the beach with him.

It is beautiful evening, calm and free.

The holy time is quiet as a Nun.

Breathless with adoration the broad sun.

Is sinking down in its tranquility.

The gentleness of heaven broods o'er the sea.

Listen! The mighty Being is awake.

And doth with his eternal motion make.

A sound like thunder - everlastingly.

(Can you find the words which give a feeling of quietness?)

\section{Figurative Language, Cliché, Jargon}

Besides the connotative meanings of words, there are other uses of language which we should be aware of before we can read critically. The first that we shall look into is figurative language or figures of speech. Like connotative words, figurative language refers to the use of words, not in their literal sense, but in a creative or imaginative way, creative writers create or use figurative language to make their writings more forceful and more vivid for the readers. Poets use a lot of figurative language, but poetry is not the only place where we will find figurative language in use. Many prose writers also use figurative language to give different meanings to otherwise common things. It helps us to see ordinary things differently, in a different light, as it were, drawing up a new image of the same old things. Millan (1987) confirms figurative language is used to give great immediacy, greater, or stronger impact on an otherwise commonplace idea. The two most common figurative language in use are metaphor and smile.

A metaphor, like smile, compares two different things. The comparison it makes is direct, that is by saying directly that something is something else, for example: an iron will, a harvest of gold, etc. When someone says: she has an iron will to succeed, we have a better idea of the quality of her will. By saying that she has a strong will we do not have any idea of how strong he will is; by using the metaphor iron with its connotations, we can easily imagine that her will is not only strong, but, like iron, it is unbendable and long lasting. The word iron connotes hardness, durability and, perhaps, also inflexibility. Thus iron will tells us something more than just strong will. Similarly the expression a harvest of gold, can 
IJOLTL, Vol. 3, No. 2, May 2018

p ISSN: 2502 2326; e ISSN: 2502 8278

Http://ijolt1.pusatbahasa.or.id; Email: ijolt1@gmail.com

Center of Language and Culture Studies, Surakarta, Indonesia

Sudrajat, Didi. 2018. Developing Critical Reading Skills for the Information

and Enjoyment. IJOLTL (2018), 3(1): 147 158. DOI: 10.30957/ijoltl.v3i2.453.

mean that the yellow color of the wheat or rice being harvested is likened to gold, with its connotation of being an expensive metal and therefore conjures up on image of valuable harvest. It can also mean that what is obtained or harvested is something of value, like gold.

A smile is an indirect comparison - that is, the comparison made by using words such as: as, like, as if, as though, and as ... as. For example, The snow covered the land like a white blanket, here the snow is likened to a blanket. Here are some more examples:

a. The water of the Dead Sea is said to be so thick that one can float there as if one's body is made of cork.

b. The baobab tree, which grows in the Kalahari Desert, has a bark that is thin and smooth, and sags in folds toward the base of the tree, like the skin of an elephant's leg.

Comparing the body to a cork and bark to the skin on an elephant's leg gives us vivid pictures of how thick the water in the Dead Sea is, and how the bark of a baobab tree looks like. The image we get is clearer than what we would get through a literal description.

Another figure of speech is cliché or trite expression. This means that once upon a time these expressions were considered very clever and effective, but because they have been used again and again, they became overused and lose their freshness and effectiveness. People who use clichés in their writing or speech are considered lacking in originality and imitators of other people. The following expressions are generally considered as clichés:

The blind leading the blind; keep the pot boiling; bite the hand that feeds you; the apple of one's eye; busy as a bee; deathly pale; humble origin; to kill the fatted calf; etc.

As we see from the above list, many of the above expressions are new for us, and we would consider them good and effective. Indeed, many expressions which are regarded as trite or hackneyed by native speakers are in fact new to non-native speakers like us because we are not familiar with the language as the native speakers. Therefore, we should not hesitate to use those expressions when we really think they are necessary, provided, of course, that we use them appropriately and do not use them too often. Here is what Altick (1951) says about using clichés:

It would be pedantic, not to say useless, to insist that good writers never, never use clichés .... But good writers, if they use clichés at all, use them with the utmost caution. In informal discourse, furthermore, clichés are almost indispensable. When we are relaxing with friends, we do not want to be bothered to find new or at least 
IJOLTL, Vol. 3, No. 2, May 2018

p ISSN: 2502 2326; e ISSN: 2502 8278

Http://ijolt1.pusatbahasa.or.id; Email: ijolt1@gmail.com

Center of Language and Culture Studies, Surakarta, Indonesia

Sudrajat, Didi. 2018. Developing Critical Reading Skills for the Information

and Enjoyment. IJOLTL (2018), 3(1): 147 158. DOI: 10.30957/ijoltl.v3i2.453.

unhackneyed ways of saying things; we rely upon our ready supply of clichés, and if we do not overdraw our account, no one thinks the worse of us. So long as we succeed in communicating to our friends the small, commonplace ideas we have in our minds no harm is done.

When we read our textbooks, e.g. on linguistics or psychology or social sciences, etc. we will find words which are often used in one textbook but not in the others. Those words are called technical words or jargon. Each field has its own jargon. Thus we have medical jargon, educational jargon, computer jargon, etc. Jargon or technical words are used by people in a certain profession- people outside that profession might not know those jargons. Jargon is useful when it used among the people of the same profession because they understand the terminology. However, jargon should not be used outside the group because it shows poor taste and pompousness.

The following is an extract from a piece of writing by Russell Baker who uses jargon to retell the story of Red Riding Hood.

One upon a point in time, a small person named Little Red Riding Hood initiated plans for the preparation, delivery and transportation of foodstuffs to her grandmother, a senior citizen residing in a place of residence in a forest of indeterminate dimension. In the process of implementing this program, her incursion into the forest was in mid-transportation process when it attained interface with an alleged perpetrator. The individual, a wolf, made inquiry as to the whereabouts of Little Red Riding Hood's goal as well as interring that he was desirous of ascertaining the contents of Little Red Riding Hood's foodstuff basket, and all that.

Russell Baker is a political writer whose column is published in many American newspapers. He rewrites this fairy tale to make fun of the worst aspects of the English language (Quoted from Milan, 1987).

\section{Distinguishing Fact from Opinion: Recognizing Fallacious Reasoning}

We have seen how language can be used to express truth or distort truth, to make something more attractive or less attractive than it really is. Connotative words are not the only device to cover truth. Faulty or fallacious reasoning is another device we should aware of. This is more difficult to detect because we have to read beyond what is stated to know what is behind the statement. To be able to do this, we should know two kinds of reasoning: inductive and deductive reasoning. 
IJOLTL, Vol. 3, No. 2, May 2018

p ISSN: 2502 2326; e ISSN: 2502 8278

Http://ijoltl.pusatbahasa.or.id; Email: ijolt1@gmail.com

Center of Language and Culture Studies, Surakarta, Indonesia

Sudrajat, Didi. 2018. Developing Critical Reading Skills for the Information

and Enjoyment. IJOLTL (2018), 3(1): 147 158. DOI: 10.30957/ijoltl.v3i2.453.

\section{a. Inductive Reasoning}

Inductive reasoning is drawing a general conclusion from many related evidence. In everyday life we often do this. After comparing the prices of several items in Supermarket A and B, we often say that supermarket A is cheaper (or more expensive) than B. Here, we are making a generalization which is not necessarily true. What about prices of other items which have not been compared? What we should have said is. Some things are cheaper (or more expensive) in A and B. Naturally we are supposed to be able to back up your statement by mentioning what things are cheaper or more expensive.

We often make sweeping generalization by omitting words such as usually, nearly all, few, seldom, often, etc. and use words like: always, never, all, only. Sometimes these words are not expressed but merely implied, e.g. Supermarket $A$ is cheaper than supermarket $B$. This statement implies that all things are cheaper in supermarket A.

Therefore, whenever we read that Asian students do better than American students in High School, we must recognize this as a generalization and that there are apt to be exceptions. Even if the words usually or some are used, we should still ask ourselves how often is usually or how many is some. This does not mean that we always ask for evidence or statistical data, but we should be aware that many statements are generalization and that exceptions do exist.

\section{b. Deductive Reasoning}

In deductive reasoning we draw a conclusion from a general to specific whereas in deductive reasoning is commonly expressed by syllogism which consists of two premises and a conclusion, for example:

Major premise : All A's are B's.

Minor premise: $\mathrm{C}$ is $\mathrm{A}$

Conclusion : Therefore $\mathrm{C}$ is $\mathrm{B}$

This syllogism is valid because the premises already imply or contain the conclusion. If we accept the premises then we must accept the conclusion. However, even if a syllogism is valid, it is not necessarily. Here is an example:

Major premise : All Balinese are artists

Minor premise: Ketut is a Balinese

Conclusion : Ketut is an artist

This syllogism is valid because it follows the correct form, nevertheless it is not true because the major premise is not true.

The syllogism itself for the deductive argument can also be invalid. Here is an example: 
IJOLTL, Vol. 3, No. 2, May 2018

p ISSN: 2502 2326; e ISSN: 2502 8278

Http://ijolt1.pusatbahasa.or.id; Email: ijolt1@gmail.com

Center of Language and Culture Studies, Surakarta, Indonesia

Sudrajat, Didi. 2018. Developing Critical Reading Skills for the Information

and Enjoyment. IJOLTL (2018), 3(1): 147 158. DOI: 10.30957/ijoltl.v3i2.453.

Major premise: FKIP Unikarta trains teachers

Minor premise: Didi Sudrajat is a teacher.

Conclusion : FKIP Unikarta trained Didi Sudrajat

A valid syllogism would be:

Major premise : FKIP Unikarta trains teachers

Minir premise : Didi Sudrajat is trained by FKIP Unikarta

Conclusion : Didi Sudrajat is a teacher.

To make valid syllogism, we must make sure that the subject of the conclusion is also the subject of the minor premise (Didi Sudrajat), and the predicate of the conclusion is also the predicate of major premise (teacher).

Another common form of syllogism is one with a negative premise as the following example shows:

Major premise : No A is B

Minor premise: $\mathrm{C}$ is $\mathrm{B}$

Conclusion $\quad: \mathrm{C}$ is not $\mathrm{A}$

Here the predicate of the major premise is also the predicate of the minor premise.

From the above examples we can say that to make valid argument or syllogisms, the idea expressed by the minor premise should be contained in the major premise. Thus, again, we cannot introduce a new or a different idea in the minor premise. Here is another example:

Major premise : If Zainuddin does not attend classes, he will fail.

Minor premise: Zainuddin will not fail

Conclusion : Zainuddin does not attend classes.

Regardless whether the conclusion is true or not, the syllogism is invalid because Zainuddin will not fail is not contained in the major premise. In order to have a valid syllogism the minor premise would have to be Zainuddin does not attend classes or Zainuddin will fail, and conclusion would then be Zainuddin will fail and Zainuddin does not attend classes, respectively.

\section{c. Opinion}

So far, we have talked about deductive and deductive reasoning, it would be useful to know more about what opinion really is. Here is a passage adapted from Beyond Feelings: A Guide to Critical Thinking by Vincent Ryan Ruggiero (1984). 
IJOLTL, Vol. 3, No. 2, May 2018

p ISSN: 2502 2326; e ISSN: 2502 8278

Http://ijolt1.pusatbahasa.or.id; Email: ijolt1@gmail.com

Center of Language and Culture Studies, Surakarta, Indonesia

Sudrajat, Didi. 2018. Developing Critical Reading Skills for the Information

and Enjoyment. IJOLTL (2018), 3(1): 147 158. DOI: 10.30957/ijoltl.v3i2.453.

\section{How Good Are Your Opinions?}

Opinion can mean two things: (1) personal preferences and (2) considered judgment. When we say that every one is entitled to his or her opinion, we are thinking of opinion as meaning personal preferences. Therefore, when somebody says: I think this car is ugly, it would be foolish and useless to challenge that statement. The person is merely stating his opinion, his personal preference, and as you have heard many times before, it is no use arguing about taste. What is beautiful to you may well be ugly to someone else. In this case, everybody is indeed entitled to his or her opinion.

However, consider this case: A newspaper reports that the Supreme Court has delivered its opinion on a certain case. Obviously this is not a statement of personal preferences or of personal likes and dislikes. In this case the Supreme Court's opinion is a careful judgment, which has been carefully arrived at, after a through inquiry and deliberation.

Most of what is called opinion falls somewhere between personal preference and careful judgment. This means that we use opinion not to mean personal preference or careful judgment. Although everyone is entitled to his or her own opinion it does not guarantee favorable consequences. It is important to remember that what we believe is not necessarily correct or true. Free societies are based on the wise observation that knowledge comes through mistakes, and because truth is elusive, every person must find his her own way to wisdom. In other words, we should realize, in doing so, we do not harm others. According to Francis Bacon in Milan (1987), there are four kinds of errors that can make people have wrong opinions: (1) error or tendencies to error are common among all person because they are human, (2) errors that come from human communication and the limitation of language, (3) errors in the general fashion or attitude of an age, and (4) errors posed to an individual by a particular situation.

In forming our opinions, it is useful to find out the views of those who know more about the subject then we do. In this way we broaden our perspective, see details we did not see before, and consider facts we were not aware of. No one can know everything. It is not a mark of inferiority but of good sense to consult those who have given their social attention to the field of knowledge at issue.

Each of us knows something about food and food preparation, but this does not make us experts on running a restaurant or on the food packaging industry. It takes more than experience to make us authorities on a particular skill or subject matter.

For all of us, whether experts or amateurs, it is natural to form opinions. We are constantly receiving sensory impressions and responding to them first on the level of simple likes and dislikes, then on the level of thought. Even if we wanted to escape having opinions, we couldn't. Nor shouldn't we want to. One of the things that makes human beings vastly more complex and interesting than plants or animals is their ability to form opinions. 
IJOLTL, Vol. 3, No. 2, May 2018

p ISSN: 2502 2326; e ISSN: 2502 8278

Http://ijolt1.pusatbahasa.or.id; Email: ijolt1@gmail.com

Center of Language and Culture Studies, Surakarta, Indonesia

Sudrajat, Didi. 2018. Developing Critical Reading Skills for the Information

and Enjoyment. IJOLTL (2018), 3(1): 147 158. DOI: 10.30957/ijolt1.v3i2.453.

This ability has two sides, though, if it can lift man to the heights of understanding, it can also topple him to the depths of ludicrousness. Both the wise man and the fool have opinions. The difference is, the wise man forms his with care, and as time increases his understanding, refines them to fit even more precisely the reality they interpret. In summary, critical reading involves reading for the academic needs and reading for enjoyment.

\section{REFERENCES}

Abbot, G., J. Greenwood D., Mc Keating, and P. Wigard. 1981. The Teaching of English As An International Language. Glasgow: William Collins Sons and Co. Limited.

Altick, Richard D., Lunsford, Andrea A. 1984. Preface to Critical Reading. New York: Holt, Rinehart and Waston, Inc.

Bastidas A. and Jesus a. 1986. The Cloze Procedures as a Teaching technique to Improve Reading Comprehension. English Teaching Forum: Vol. XXIV, Number 1.

Budiharso, Teguh. 2006a. English Language in Teaching: Discourse Analysis, and Contrastive Rhetoric. Samarinda: Certel Books.

Budiharso, Teguh. 2006b. Rhetoric and Linguistic Features: A Contrastive Rhetoric Analysis of Essay Writing. Yogyakarta: Stepa Publishing.

Budiharso, Teguh. 2006c. Pengajaran Bahasa Berbasis Konteks dalam Perspektif Analisis Wacana dan Linguistik. Surakarta: Penerbit Pustaka Cakra.

Calfee, Robert, and Priscilla Drum. 1985. Handbook of Research on Teaching. New York: Macmillan Publishing Company.

Carrell, Patricia, and Joan C. Eisterhold. 1983. Schema Theory and ESL Reading Pedagogy. TESOL QUATERLY, 17(4).

Citrobroto, S. 1984. Prinsip-Prinsip dan teknik Berkomunikasi. Jakarta: Bhatara Karya Aksara.

Dwyer, Margareth A. 1983. Some Strategies for Improving Reading Efficiency. English Teaching Forum, 11(3).

Grellet, Francois. 1984. Developing Reading Skills. Cambridge: Cambridge University Press.

Hafni. 1981. Pemilihan dan Pengembangan Bahan Pengajaran Membaca. Jakarta: Departemen Pendidikan dan Kebudayaan.

Lewis, John F. 1978. Teaching English. New York: American Book Company.

Millan, Deane K. 1987. Developing Reading Skills. New York: Random House.

Oslon, A. and W.S. Ames. 1972. Teaching Reading Skills in Secondary School. New York: International Textbook Company.

Strevens, Peter. 1983. New Orientations in Teaching of English. Oxford: Oxford University Press. 
IJOLTL, Vol. 3, No. 2, May 2018

p ISSN: 2502 2326; e ISSN: 2502 8278

Http://ijolt1.pusatbahasa.or.id; Email: ijolt1@gmail.com

Center of Language and Culture Studies, Surakarta, Indonesia

Sudrajat, Didi. 2018. Developing Critical Reading Skills for the Information and Enjoyment. IJOLTL (2018), 3(1): 147 158. DOI: 10.30957/ijoltl.v3i2.453. 